\section{Pathology - The Science Behind Cure}

Prof. Dr. Syed Mukarram Ali

MBBS, MPhil, DCP, DPath, FRC Path, FCPS (Hon)

Honorary Professor of Pathology, BCPS, Dhaka

Chairman and Managing Director

Delta Medical College and Hospital

Pathology, the heart of modern health care service, is a science behind cure. ${ }^{1}$ If you have ever had a serious illness like cancer, the person- who made the diagnosis on which your treatment was based is a Pathologist. Pathology as such started with the autopsy. It began during Renaissance in Italy and it worked in the following way - a physician would follow a patient and if that patient died the physician would perform an autopsy to understand reasons for signs and symptoms. Most people did not record their experiences or books were lost. One of them, Antonnio Benivieni, was very good in describing the experiences both clinical and pathological of autopsies. After his death his brother found his record book and had it published in 1507. It is recognized as the first book in Anatomic Pathology. ${ }^{2}$

The physician who did the autopsy would write to the patients' relatives explaining what he had found and giving them advise and so forth.

From Italy the discipline moved to England with pretty much the same approach - from England it moved to France till 1600-1700 and from France went to Germany in 1800 where it took a very significant turn under the influence of Rudolph Virchow. Virchow was a scientist - he was not very interested in diagnostic pathology. He was interested in understanding the mechanism of disease and almost single handedly he transformed pathology into science and scientific basis of disease. Pathology was imported to USA in late 1800 through German scholars therefore replicated German philosophy. 3

Pathologist unfolded under the microscope - the mechanism of the disease to understand the disease and disease process. As such pathology is the very cornerstone of modern medicine - a science which has progressively replaced the myth, magic and superstition of traditional medicine with a rational basis for the care of the sick. The subject expanded tremendously with the development of science and technology and pathology is now subdivided in many branches like histopathology, microbiology, haematology, clinical chemistry, immunology, molecular biology, etc. which are all actively taking part for diagnosis of disease and advice the clinician who then can give proper treatment to the patient. "The improved understanding of human genome is beginning to bear fruit in respect of understanding how disease is caused" said Sir John Bell in his prestigious Harveian lecture at the Royal College of Physicians London in 2010. He included all disease not just conventionally regarded as 'inherited' and emphatically included cancer, a disease caused by acquired abnormalities of genome, therefore genomics supported by bioinformatics will tell us all we need to know about the nature and behavior of neoplasm and hence will provide its diagnosis and classification. 4,5

The pathologists are now using sophisticated technique like PCR, FISH, CGH and DNA sequencing for making accurate diagnosis, classification, prognosis as well as appropriate targeted therapy. But the popular image of the pathologist somewhat socially dysfunctional, loner, turns out to be a myth. In many countries there is a misconception about pathologist because they are back room boys doing work in the laboratories. People don't see them face to face and common people have got very little knowledge about their actual work.

In a survey in UK only less than $30 \%$ population could say properly what the actual function of a pathologist is. Majority of the people in UK are in the opinion that they are involved in dissecting dead bodies and reporting medicolegal cases only - therefore call 'Doctors of Dead'.

Majority people don't think pathologist help doctors to give correct treatment, diagnosis of cancer, conduct lab test or diagnose disease. Many think they do stool, urine and blood test only. Only single figure percentage 
think pathologists diagnose cancer, control infection and advise clinicians to guided therapy to cancer.

Now a days in the Western world there is a negative feeling of decline in autopsies which Clinician think that it is no longer required in this modern technological breakthrough as they know the cause of death already by various specialized test. This has proven incorrect by series of studies, some published in the "New England Journal of Medicine"- which says that "This is absolutely not true". 6 Many new disease are coming up about which we yet don't know what changes happen in different organs. There is tissue transplantation developing very fast and we don't know many things about it and effects by new drugs which are coming in the market and their effects are also unknown.

One main cause of decline is Economic. The other cause is fear of clinician of being sued by the patient's relatives should the autopsy find something which the clinicians did not see.

What should the Pathologist of our country do?

In the context of adverse comments in different media about the errors in diagnosis the pathologists in collaboration with medical societies and BMA should pay a considerable attention to the public perception of pathologists work and simultaneously attempt to clear the name of the profession, which has done less wrong than many other clinical disciplines who remain subject of public admiration.

If you are interested, have a look at the Lancet: vol. $335,2027-2031$, there is error in diagnosis all over the world; more over the error rates in diagnosis are five times higher than those of pathologists. 7 The Pathologist therefore should urge the public to understand and the administrators and politicians have to be honest to admit, that there is No Zero error rate in any branch of medicine, any more than any field of human endeavor. They should also urge the authorities to introduce Medical Audit for the sake of public interest and clearing the bad names of the Doctors as a whole. In this connection again the role of autopsy comes and the pathologists are the persons who are responsible for this. We therefore urge our clinicians and pathologists to introduce medical autopsies in our country at least in teaching hospitals.

Delta Med Col J. Jan 2013;1(1):1-2

\section{References}

1. Pathology: the science behind the cure. The Royal College of Pathologists. Review of UK Health Research Funding - The Cooksey Review. [Internet]. 20 July 2006 [cited 2013 April 4]. Available from:www.rcpath.org/.../C/CookseyReview-CollegeRe sponse-July06.pdf.

2. Benivieni A. The hidden causes of disease (translated by Charles Singer). C. Thomas Publisher;1954.

3. Rudolf Virchow (German scientist) - Britannica Online Encyclopedia. [Internet] [cited 2013 April 11]. Available from:

www.britannica.com/EBchecked/topic/629797/RudolfVirchow.

4. Bell J. Redefining disease. The 2010 Harveian oration. The Royal College of Physicians of London, 2010.

5. Furness $P$. The future of cellular pathology: the next 50 years. The Bulletin of the Royal College of Pathologists. 2012;160:222-26.

6. Siebert JR. A matter of life and death: conversations with pathologists. Pediatric and Developmental Pathology.2009;12(4):310.

7. Sonderegger-lseli K, Burger S, Muntwyler J, Salomon F. Diagnostic errors in three medical eras: a necropsy study. Lancet.2000;355(9220):2027-31. 